\title{
PEMBENTUKAN LINGKUNGAN BAHASA ARAB UNTUK MENGEMBANGKAN KETERAMPILAN BERBICARA
}

\author{
Irhamudin Abdullah', Novita Rahmi' ${ }^{1}$, Walfajri' \\ ${ }^{1}$ Institut Agama Islam Negeri (IAIN) Metro Lampung \\ E-Mail:airhamudin@gmail.com
}

\begin{abstract}
This study aims to determine that the formation of the language environment is a major factor in the success of learning foreign speaking skills especially Arabic. The method used is the library research method (library research), data collection is done by examining and exploiting several journal articles, books, and other sources of information deemed relevant to the study. The formation of a language environment is one of the dominant factors supporting the success of learning Arabic speaking skills. It can be seen that speaking skills are very important language skills. Without an optimal language environment, it is difficult to master it. The results of this study are that the formation of the language environment must be the responsibility of the school manager and all boarding officials by involving all students. Thus, all parties will feel the language environment and support wholeheartedly towards all programs related to the language environment. The formation of the language environment can be done through various linguistic activities, including: developing vocabulary (mufrodat), displaying Arabic vocabulary (posters) in language environment facilities, Arabic language practices in daily communication, Arabic speech and drama practices.
\end{abstract}

Keywords: Language Environment, Speaking Skills, Arabic

\begin{abstract}
Abstrak
Penelitian ini bertujuan untuk mengetahui bahwa strategi pembentukan lingkungan bahasa menjadi faktor utama dalam keberhasilan pembelajaran keterampilan berbicara asing khusunya Bahasa Arab. Metode yang digunakan adalah metode kualitatif deskriptif. Penelitian ini dilakukan di asrama MAN 1 Metro. Pengumpulan data dilakukan dengan cara observasi dan wawancara mendalam serta menelaah dan mengekploarasi beberapa artikel jurnal, buku-buku, dan sumber informasi lainya yang dianggap relevan dengan kajian. Instrumen ini digunakan guna untuk mengumulkan data-data tentang strategi pembentukan lingkungan berbahasa Arab untuk meningkatkan keterampilan berbicara. Dapat diketahui bahwa keterampilan berbicara merupakan keterampilan bahasa yang sangat penting. Tanpa lingkungan bahasa yang optimal, sulit untuk menguasainya. Adapun hasil dari penelitian ini adalah Pembentukan lingkungan bahasa harus menjadi tanggung jawab pengelola sekolah dan semua pengurus asrama dengan melibatkan seluruh siswa. Dengan demikian, semua pihak akan merasakan lingkungan bahasa dan mendukung sepenuh hati terhadap semua program yang terkait dengan lingkungan bahasa. Pembentukan lingkungan bahasa dapat dilakukan melalui berbagai aktifitas kebahasaan, antara lain : pengembangan kosa kata (mufrodat), pemajangan kosa kata bahasa arab (poster) di fasilitas lingkungan bahasa, praktek bahasa arab dalam komunikasi sehari-hari, praktek pidato dan drama bahasa Arab.
\end{abstract}

Kata Kunci :Lingkungan Bahasa,Keterampilan Berbicara,Bahasa Arab 


\section{PENDAHULUAN}

Suatu sistem pebelajaran bahasa Arab semakin variatif dengan berkembangnya pemikiran manusia. Salah satu cara yang dapat menunjang pengembangan keterampilan berbahasa seseorang yaitu dipengaruhi oleh lingkungannya. Kesulitan yang dirasakan oleh para siswa dalam pembelajaran bahasa khususnya dalam mengembangkan keterampilan berbicara karena tidak adanya lingkungan bahasa yang dapat diterapkan dengan baik.

Penelitian masalah yang menjelaskan bahwa lingkungan berbahasa dapat membantu dan memberikan pengaruh dalam mengembangkan keterampilan berbicara. Serta membentuk strategi dalam pembentukan lingkungan yang berbahasa. Sebuah penelitian mengatakan bahwasannya kanak-kanak yang tinggal di lingkungan linguistik tertentu akan jauh lebih cepat dan lebih mudah untuk belajar bahasa daripada anak-anak yang berada di luar lingkungan linguistik yang sedang dipelajari (Sholeh, 2017). Tetapi tidak menjamin bagi siswa memenuhi syarat dalam bahasa jika tidak ada data input dalam bentuk penggunaan yang baik dari bahasa target, walaupun telah melakukan perancangan pengajaran yang hendak diterapkan (Unsi, 2015). Secara umum, kemampuan anak untuk berbicara diperoleh dari lingkungan di mana ia hidup melalui peniruan dan berkembang secara alami. Jika tidak ada lingkungan bahasa, maka tidak ada upaya otomatis untuk memperoleh bahasa. Jadi untuk mendapatkan bahasa dan menggunakannya dengan terampil, Anda memerlukan lingkungan bahasa (Putri, 2013).

Penelitian ini akan memberikan mengamati tentang cara atau stretegi dalam pembentukan lingkungan berbahasa Arab dalam proses mengembangkan keterampilan berbicara. Lingkungan berbahasa menjadi fasilitas siswa dalam memperoleh pengetahuan berbahasa. Keterkaitan antara lingkungan bahasa dengan aspek yang mendukung pada proses mengembangkan keterampilan berbicara, baik dari perilaku manusia, alam dan tempat itu sangatlah penting untuk menunaikan keterampilan berbicara bahasa Arab. Sejalan dengan sasaran tersebut pertanyaan dirumuskan : Bagaimana strategi pembentukan lingkungan berbahasa Arab ? Jawaban atas pertanyaan ini dapat memberikan partisipasi kepada pengelola lembaga dalam melaksanakan proses pembelajaran bahasa Arab.

Penelitian ini berlandaskan pada asumsi utama. Lingkungan berbahasa terbukti menjadi sarana utama dalam pengembangan pembelajaran bahasa arab terutama pada keterampilan berbicara. Lingkungan bahasa juga membrikan kesempatan kepada siswa untuk mengembangkan keterampilan berbahasa Arab yang dimilikinya. Singkatnya, tujuan pembentukan lingkungan berbahasa adalah untuk meningkatkan kemampuan siswa dalam keterampilan berbicara secara aktif.

\section{KAJIAN TEORI}

1. Keterampilan Berbicara Bahasa Arab

Keterampilan berbicara merupakan suatu upaya manusia dalam ucapannya melafadkan kosa kata maupun membunyikannya dengan tujuan mengutarakan ekspresi, gagasan, ide dan apa yang dirasakannya. Kemudian, akan direspon oleh pendengar dengan cara menerima informasi tersebut dari intonasi, mimic dan tekanan. Rosyidi dan Ni'mah mengatakan, salah satu hal yang penting dari unsur kebahasaan adalah ketrampilan dalam menguasai bahasa itu sendiri. Hal itu juga disebut sebagai faktor yang mendasari pembelajaran bahasa asing karena proses tersebut ditangkap untuk dipelajari oleh guru. 
Tarigan menekankan bahwa keterampilan berbicara dapat mendukung keterampilan bahasa lainnya. Dari definisi ini dapat disimpulkan bahwa saat belajar bahasa maka akan ikutserta dalam proses komunikasi. Dalam proses pembelajaran bahasa Arab, tujuannya adalah untuk menguasai skill komunikasi baik itu verbal dan non verbaldengan baik dan benar.Seseorang dianggap dapat berbicara selama dia dapat berkomunikasi dengan lawan bicara (Dluhriah, 2017).

Dalam kegiatan berkomunikasi, pembicara berperan sebagai penyampai informasi yang akan ditangkap oleh orang lain sebagai penerima informasi atau responder dalam menerima sebuah pesan yang disampaikan. Pesan disini merupakan objek yang terdiri dari informasi yang dikirimkan oleh pengirim, yang akan menghasilkan umpan balik atau Feed back oleh receiver berupa reaksi.

Pada awal metahih kemampuan bicara, maka akan lebih dahulu harus memiliki dasar skill mendengarkan kemudian penguasaan kosa kata dan memberanikan diri untuk menunjukkan ekspresi dari apa yang dipikirkan atau dirasakannya (Unsi, 2015). Berbicara sebagai aktivitas komunikasi melibatkan proses pembicaraan yang saling memberi umpan balik terhadap sender dan receiver. Adanya timbal baliktersebut fungsinya adalah untuk menyampaikan dan menerima informasi dan direspon satu sama lain dengan cara sitematis sehingga terjadilah didalamnya sebuah proses komunikasi (Setyonegoro, 2013). Feed back tersebut jika terjadi ketidakpahaman yang sama anatar ke dua pihak yang terlibat dalam proses komunikasi, akan menyebabkan mis understanding atau mis communication sehingga kemungkinan terjadi perdebatan.

Keterampilan percakapan dapat dipelajari. Belajar berbicara adalah suatu usaha supaya dapat berbicara dengan baik dan benar. Berawal dari ucapan vocal, maka terjadilah ucapan yang memiliki arti sehingga dapat diterima oleh receiver. upaya untuk dapat berbicara dengan baik. Dari pengucapan vokal, peningkatan dipraktekkan ke bentuk ucapan yang bermakna. Demikian pula, seseorang bisa melakukan komunikasi antar seseorang lainnya melalui prosedur yang lebih kompleks yang dapat ditingkatkan dengan cara terus berlatih (Setyonegoro, 2013). 2. Jenis Keterampilan Berbicara Bahasa Arab.

Dr. Salah 'Abdul Majid Al-Arabi menuturkan bahwa keterampilan berbicara ada dua macam yaitu (Al-'Arabi, t.t.) :

a) Maharah An-Nuţqi (مهارة النطق)

Keterampilan berbicara ini adalah kemampuan mengungkapkan kata-kata dengan tanpa memerlukan banyak berfikir. Diantara contoh kemampuan ini adalah mengulangi atau menirukan kata-kata (ungkapan) yang dilafalkankan oleh guru atau orang lain. Ungkapan atau kata-kata itu bisa dari bacaan yang dikeraskan, hapalan teks-teks yang tertulis atau dari sesuatu yang ia dengarkan.

b) Maharah Al-Hadiś (مهارة الحديث)

Keterampilan berbicara ini adalah kesempurnaan dari kemampuan atau maharah ini karena Maharah Al-Hadiś (مهارة الحديث) tidak akan sempurna kecuali menghadirkan minimal dua orang yaitu satu yang bicara (المتحدث) dan satunya pendengar. Dimana antara keduanya saling bergantian sehingga berjalanlah dialog antara keduanya. 
Adapun jenis-jenis keterampilan berbicara bahasa Arab menurut Abd. Wahab Rosyidi dan Mamlu'atun Nafisah antara lain (Unsi, 2015):

\section{1) Muhadatsah (percakapan)}

Merupakan salah satu bentuk penyajian pembelajaran bahasa arab dengan cara menerapkan percakapan. Secara tidak langsung, muhadatsah dapat menambahkan dan terus memperkaya kosa kata (mufrodat) pada siswa. Pada dasarnya tujuan muhadatsah adalah untuk melatih peserta didik untuk berbicara dengan fasih dan mampu memahami apa yang dikatakan musuh atau orang lain. Dengan demikian aspek kemampuan yang harus dimiliki agar bisa berdialog adalah: mampu mendengarkan ucapan dengan baik, memahami setiap ungkapan yang ditangkap, fasih dalam mengucapkan kata-kata serta berkemampuan untuk menyusun kalimat secara benar. Sasaran yang bisa dilihat dari ajaran muhadatsah adalah: a) mampu melafadzkan bahasa Arab dengan fasih, b) Mempu mengungkapkan peristiwa yang disaksikan menggunakan bahasa Arab dengan benar, c) mampu memahami, menerjemahkan, dan mengkomunikasikan kembali percakapan orang lain.

2) Ta'bir syafahi (Ungkapan secara lisan)

merupakan kegiatan praktikum membuat suatu karya tulis berupa karangan yang memiliki tujuan untuk mengasah kemampuan untuk mengekspresikan pikiran dan perasaan mereka. Melalui latihan ini, murid dapat menguasai kosakata, memilih kata dan menyusun kalimat yang benar, dan sistem suara seperti nada, ritme, dan alunan. Prinsip ta'bir syafahi harus dipertimbangkan mengikuti studinya adalah: cerita, debat, pidato, seminar, dongeng, proses pembelajaran, mengungkapkan pendapat, mengajukan pertanyaan, permintaan maaf, terima kasih, permintaan, selamat datang, selamat tinggal, dan sebagainya. Sesuai dengan ini, Aziz dan AlWasilah menyebutkan bentuk dari maharah al-kalam diantaranya: a) cakap dalam berkomunikasi menggunakan Bahasa Arab dengan benarbaik qawaid, ushlub, dan makhroj, b) mahir berbicara, bercerita, berdiskusi, menerjemahkan, dan mengekspresikan pendapat dengan bahasa Arab (Unsi, 2015).

3. Tujuan Keterampilan Berbicara Bahasa Arab.

Keterampilan Berbicara adalah kemampuan menyalurkan gagasan, pemikiran, perasaan dan keinginannya kepada lawan bicara (Hermawan, t.t.). Tarigan mengungkapkan bahwasannya berbicara adalah suatu pengkombinasian antar faktor fisik dan psikis, neurologis, sematik dan linguistic secara luas sehingga dapat dianggap sebagai alat manusia yang paling penting bagi kontrol sosial (Tarigan, 2013). Tujuan berbahasa Arab yakni untuk dapat dikomunikasikan lewat percakapan. William Moulton menyatakan "Bahasa merupakan ucapan yang dibiasakan" (Dahlan, 1992). Untuk memahami bahas, maka diperlukan kegiatan menyimak oleh siswa supaya mereka dapat menirukan dan merespon sesuai dengan ucapan atau intonasi native speaker. Bahasa Arab sebagai bahasa asing yang dipelajari siswa, memiliki empat ketrampilan dasar, yakni: mendengarkan, berbicara, membaca dan menulis.

Penjelasan diatas menyebutkan bahwa penguasana berbahasa Arab dipengaruhi oleh unsur dasar bahasa itu sendiri yakni empat ketrampilan diatas. Meskipun demikian pada intinya bahasa merupakan keterampilan-keterampilan yang bersifat komunikatif dan berpusat pada keterampilan berbicara. Yang dimaksud dengan kalam (berbicara) adalah kemampuan mengungkapkan dengan lisan tentang perasaan manusia sesuai dengan masyarakat, politik, ekonomi dan 
budayanya dengan cara bertangungjawab dengan benarnya ucapan dan baiknya penyampaian.

Maka secara umum keterampilan berbicara memiliki tujuan agar para murid dapat mempelajari proses komunikasi dengan baik dan benar. Selain itu, diharapkan siswa mampu berkomunikasi dengan lancar dnegan pihak lawan bicara sehingga akan memberikan feed back positif berupa saling mengerti dan dapatt saling menerima satu sama lain untuk menyampaikan pesan atau informasi. lingkungan bahasa juga harus dipertimbangkan untuk memberikan wadah sebebasbebasnya untuk para siswa dapat berlatih bahasa Arab dengan baik.

4. Pengertian Lingkungan Bahasa Arab

Stephen D. Krasen mengatakan bahwasannya, dinilai lebih memberikan keefektifan pembelajaran apaila menerapkan metode pengajaran dengan memberlakukan lingkungan fokus bahasa didalamnya. Karena, lingkungan adalah pengaruh yang signifikan dalam pendidikan dan pengajaran anak-anak, khususnya ketrampilan berbahasa, dikaenakan lingkungan memiliki pengaruh pada siswa secara langsung dengan menerapkan teori yang mereka pelajari ketika mereka berada di kelas (Habibah, 2016).

Bî'ah dalam artian bahasa Indonesia berarti lingkungan (Yunus, 1990). Dan Árabiyah adalah bahasa arab. Jadi Bî'ah Árabiyah, memiliki artian lingkungan yang mencakup aktifitas pembelajaran berbahasa Arab. Tujuan diadakannya lingkungan bahasa Arab adalah sebagai wadah penyalur belajar keterampilan berbahasa Arab sebagai bahasa Asing untuk dikuasai para siswa.

Sejalan dengan semakin berkembang pesatnya pemikiran di bidang pendidikan pada abad dua puluh di bidang bahasa memunculkan sebuah keyakinan bahwa siswa berkemampuan untuk memahami sebuah bahasa dengan cara banyak mendengar bahasa tersebut, dan mampu belajar berbicara bahasa tersebut dengan banyak menggunakannya untuk berbicara dengan mengkaitkan tema pembicaraan dengan situasi yang sesuai. Maka para siswa bisa demikian itu bila pembelajarannya mengunakan pembiasaan ini.

Begitu juga siswa akan dengan mudah mempelajari bahasa Asing dan terbiasa mengunakannya bila lingkungan tempat para siswa belajar sudah mengunakan bahasa tersebut (dalam hal ini bahasa Arab terbentuk Bî́ah Árabiyah). Penerapan Bi'ah Árabiyah (lingkungan bahasa arab) menjadi salah satu aspek penting yang dapat memberikan semangat para siswa aau santri untuk mengembangkan kemampuan dan potensi diri dalam bidang penguasaan bahasa Arab. Selain itu nuansa pembelajaran yang terjadi di lingkungan bahsa Arab juga termasuk menantang skill para siswa maupun santri dengan penuh rasa berani dan kepercayaan dirinya (Nurhidayati, 2003).

Bî'ah Árabiyah(lingkungan bahasa arab) merupakan aspek non linguistik yang sangat mempengaruhi keberhasilan pembelajaran bahasa arab (Hermawan, t.t.). Karena keefektifan pembelajaran yang ada didalamnya mampu membuat para murid menjadi ekspresif dengan kebebasan dan cara mereka mempraktikkan komunikasi. Adanya lingkungan bahasa juga sangat dinilai dapat memberikan pemahaman lebih cepat dibanding yang belajar di luar lingkungan bahasa. Dikarenakan lingkungan bahasa Arab ini dimaksudkan agar para siswa dapat secara terus menerus berkomunikasi menyampaikan maksud serta pikirannya terhadap yang lainnya.

Bî'ah Árabiyah (lingkungan bahasa arab) ini bisa juga tercipta dari suatu lingkungan dimana tersedianya media pendukung seperti TV, telpon, majalah koran 
dan sebagainya (Hermawan, t.t.). Maka menciptakan Bî'ah Árabiyah (lingkungan bahasa arab) oleh guru atau lembaga pendidikan merupakan langkah tepat dalam pembelajaran bahasa arab. Karena itulah, guru bahasa Arab idealnya dapat menerapkan bahasa Arab dalam proses pembelajarannya karena itu bagian dari Bî̀ah Árabiyah (lingkungan bahasa arab).

5. Jenis Lingkungan Bahasa.

a) Lingkungan Bahasa Formal (bi'ah lughawiyah isthinaiyah)

Dulay dan Ellis (dalam Chaer, 1995) menjelaskan bahwa lingkungan formal adalah salah satu lingkungan pembelajaran bahasa yang berfokus pada penguasaan aturan bahasa yang dipelajari secara sadar. Bahkan, lingkungan bahasa formal tidak terbatas pada ruang kelas karena penting dalam lingkungan formal ini bahwa siswa bisa mengerti adanya peraturan yang diterapkan pada pembelajaran bahasa kedua yang diajarkan oleh guru di dalam kelas dengan sadar. Lingkungan penting menekankan perintah bahasa dalam pembelajaran sadar. Sehubungan dengan hal ini, Krashen menyatakan bahwa lingkungan linguistik formal memiliki karakteristik: Bersifat buatan, siswa diarahkan untuk melakukan kegiatan linguistik dengan aturan bahasa yang telah dipelajari dan umpan balik guru dalam bentuk koreksi terhadap kesalahan yang dilakukan oleh siswa dan bagian dari pengajaran umum bahasa di sekolah atau di kelas (Wassid \& Sunendar, 2008).

b) Lingkungan Bahasa Informal (bi'ahlughawiyahthabi'iyah)

Lingkungan informal adalah segala sesuatu yang siswa dengar dan amati sehubungan dengan bahasa kedua yang mereka pelajari. Lingkungan informal bersifatnatural bukan buatan. Yang di dalamnya terdapat cakuan bahasa yang digunakan pada keseharian oleh mereka, wali atau orang tua, bahasa yang dipelajari oleh anggota kelompok etnis, yang digunakan oleh media massa, bahasa guru baik di dalam kelas maupun di luar kelas. Secara umum, lingkungan sangat berpengaruh pada hasil belajar bahasa kedua siswa (Chaer, 1995). Lingkungan linguistik informal (alami) baik di lingkungan asing (foreigh environtment) ataupun di lingkungan sendiri (host environtment), yang dinilai bisa memperkaya dan mendukung perkembangan ketramilan berbahasa. Karakteristik lingkungan informal yang mempengaruhi trend pembelajaran dan kualitas hasil belajar dipengaruhi oleh empat faktor, termasuk: Sifat alami bahasa target, cara siswa berkomunikasi dalam bahasa kedua, ketersediaan model yang dapat ditiru untuk berbahasa dan ada lingkungan linguistik yang mampu mendukung komunikasi (misalnya, ada banyak teman atau pembicara yang telah belajar bahasa kedua).

Penjabaran diatas dapat ditarik simpulan bahwasanya suatu ligkungan informal dapat menjadi data masukan yang baik untuk para murid. Sehingga jika data tersebut mengendapakan menjadi pengetahuan linguistic yang sangat bermanfaat untuk berkomunikasi dwibahasa dan dapat dijadikan alat monitoring (Unsi, 2015).

\section{METODE PENELITIAN}

1. Jenis dan Sifat Penelitian

Model penelitian yang diaplikasikan peneliti untuk penelitiannya yakni kualitatif deskriptif karena secara umum penelitian ini bertujuan untuk menggambarkan, memahami serta menjelaskan suatu pokok masalah dengan menganalisis secara subtantif melalui konsep- konsep hasil dari data empiris. Peneliti terlebih dahulu terjun ke lapangan untuk mengidentifikasi masalah yang diteliti. Kemudian peneliti mengumpulkan data-data dan sumber informasi yang mendukung proses pembentukan lingkungan berbahasa baik dari sarana \& 
prasarana ataupun fasilitas pendukung lainya.

2. Lokasi dan Sumber Data Penelitian

Lokasi penelitian ini terletak di Asrama MAN 1 Metro, tepatnya di Jl.Lembayung 38 B Banjarrejo Kec. Batanghari Lampung Timur (Kampus 2 MAN 1 Metro).

3. Metode Pengumpulan Data

Teknik pengumpulan data pada penelitian ini menggunakan metode wawancara. Wawancara digunakan untuk mengumpulkan data-data tentang strategi pemebentukan lingkungan berbahasa Arab untuk meningkatkan keterampilan berbicara bahasa Arab di asrama MAN 1 Metro. Peneliti juga menggunakan metode partisipan, dimana peneliti mengikuti kegiatan sehari-hari baik individu maupun kelompok. Hal ini dilakukan oleh peneliti guna mendapatkan data strategi pembentukan lingkungan berbahasa Arab di asrama MAN 1 Metro. Peneliti juga melakukan wawancara kepada pengurus asrama MAN 1 Metro untuk mendapatkan keterangan mendalam dari berbagai aspek, baik itu aktifitas lingkungan bahasa ataupun fasilitas yang mendukung proses meningkatkan keterampilan berbicara bahasa Arab. Dan sekaligus menggali teori dari data pustaka seperti buku, jurnal ilmiah, serta kamus, dengan cara membaca, mencatat, dan mengolah bahan penelitian tersebut. Tujuan penulis menggunakan metode ini adalah untuk mencocokkan mengenai masalah/data di lapangan dengan teoriteori yang terkait.

\section{HASIL PENELITIAN}

Pembentukan lingkungan berbahasa Arab di asrama MAN 1 Metro menjadi komitmen dan tekad bagi pimpinan dan pengasuh dalam merealisasikan pembelajaran yang menyenangkan dan komunikatif. Kemampuan pengasuh juga menjadi hal utama dalam keberhasilan dalam pembentukan lingkungan berbahasa yang efektif. Karena pengasuh berperan sebagai penggerak dalam pembentukan lingkungan berbahasa Arab ini. Sarana dan prasarana pun menjadi faktor pendukung dalam proes pembentukan lingkungan berbahasa Arab dan menyesuaikan kebutuhan secara global.

Sistem KMI pondok pesantren modern Darussalam Gontor, Ponorogo adalah kiblat dari pengelolaan sistem lingkungan berbahasa Arab di asrama MAN 1 Metro. Proses belajar mengajar yang diterapkan di asrama ini tidaklah berbeda denga madrasah pada umumnya. Selain ilmu agama dan bahasa Arab juga mengajarkan ilmu umum lainnya. Hal ini dilaksanakan tidak seluruhnya, karena asrama juga mengikuti kurikulum Madrasah yang berlaku. Juga merupakan cara agar siswa tidak hanya paham akan ilmu agama dan bahasa Arab saja, melaikan "melek" kan ilmu teknologi dan sains. Pembelajaran yang dilaksanakan di asrama ini dibagi menjadi beberapa cabang ilmu yaitu : Nahwu dan Shorof, Muthola'ah, Mahfudzot, Insya dan Imla'. Pengajar dari pada ilmu-ilmu tersebut berasal dari pondok modern Gontor dan Madinah lampung timur.

Menurut Ustadz Rokiban yang merupakan pimpinan asrama MAN 1 Metro mengatakan " Para siswa diajarkan untuk bersungguh-sungguh dan disiplin dalam berbahasa, kegiatan yang mendukung dalam meningkatkan keterempilan berbicara diantaranya muhadatsah(latihan percakapan) dan muhadhoroh(latihan berpidato). Adapun mekanisme yang digunakan adalah dengan membentuk "Markaz Al Lughoh". Pembentukan lingkungan berbahasa Arab ini adalah strategi yang terbukti mampu mempengaruhi keterampilan berbicara bahasa Arab. Adapun menjadikan 
sistem wajib berbicara bahasa Arab di asrama tersebut menjadikan siswa mepelajari bahasa Arab terus menerus dan secara bertahap dalam kegiatann seharihari. Penguatan serta pengawasan dari pengasuh dan penggerak bahasa adalah faktor keberhasilan siswa dalam keterampilan berbicara bahasa Arab (Rokiban, komunikasi pribadi, 10 Juni 2020). Dorongan yang berikan oleh pengasuh dalam pembentukan lingkungan berbahasa Arab secara intensif dan motivasi juga menambah antusiasme siswa.

Membangun citra positif dengan tekad yang kuat dalam pembentukan lingkungan berbahasa di asrama MAN 1 Metro juga sering dianggap terlalu sulit oleh siswa, karena terciptanya lingkungan berbahasa Arab yang kondusif tanpa disadari mereka akan merasa nyaman dan tidak tertekan sehingga mereka mampu mengikuti pembeajaran dengan baik dan kondusif. Strategi yang dapat diterapkan dalam pembentukan lingkungan berbahasa Arab yaitu:

(1) Pengembangan kosa kata bahasa Arab.

Pengembangan kosa kata bahasa Arab dilakukan setiap pagi setelah tadarus Al-Qur'an Ba'da sholat subuh. Kosa kata diberikan kepada santri 3-5 kosa kata baru yang dilakukan secara terus-menerus. Kosa Kata/Mufrodat yang telah diberikan dikembangkan dalam latihan membuat kalimat Berbahasa Arab.Menghafal dua mufradât (kosa kata) setiap hari. Setiap siswa diwajibkan memiliki kamus dann diharuskan berbicara dengan bahasa Arab ketika berbicara atau bercerita pada teman lainnya.

(2) Pemajangan kosa kata berbahasa Arab di fasilitas umum.

Memasang dan menempel poster Berbahasa Arab di fasilitas umum diantaranya: dapur bertuliskan "Mathbah" kamar pengurus "Hujrohtul Mudabbir" kamar mandi "Hamam" dan ditempat-tempat yang setiap hari melakukan aktifitas sehari-hari. Kegiatan ini dilakukan sebagai kreatifitas santri dan diganti setiap dua minggu sekali. Memberikan hiasan yang semenarik mungkin agar para santri tertarik untuk melihatnya.

(3) Mempratekan bahasa Arab di dalam komunikasi sehari hari.

Proses mewajibkan menggunakan bahasa secara terus menerus dan berulang-ulang akan membentuk suatu kebiasaan dalam proses komunikasi dengan siswa asrama menggunakan bahasa Arab, baik saat belajar formal ataupun saat aktifitas di asrama, di lapangan, di masjid dan seluruh tempat yang menjadi lingkungan berbahasa Arab. Membentuk kegiatan latihan percakapan berpasangpasangan yang dilakukan secara terus menerus dan akan dibimbing langsung oleh para asatidz-asatidzah. Demi terjaganya proses yang konsisten, dalam hal ini pemberian punishment kepada sisiwa yang melanggar dilingkungan bahasa dapat mendorong dan meningkatkan kemampuan siwa dalam berbahasa Arab., di antaranya santri diberikan sanksi dengan menghafal sepuluh kosa kata baru, menulis tulisan bebas atau insya'. Tujuan diadakannya punismen yakni untuk menjaga konsistensi selain itu melatih siswa ata santri secara tak langsung pada penguasaan bahasa secara ucapan dan tulisan. Artinya, maharah kalam dan kitabah adalah kemampuan yaktif yang harus siswa atau santri lakukan dan terapkan di daerah-daerah bagian asrama yang telah diberlakukan aturan berbahasa Arab.

(4) Praktek pidato bahasa Arab.

Kegiatan praktek bahasa Arab di sebut muhadoroh. Praktik ini ditujukan untuk para santri lebih tepatnya untuk memperbaiki kesiapan mentalnya di depan banyak orang nantinya. Dan kegiatan ini juga untuk melatih pelafalan berbahasa Arab. Kegiatan ini dilakukan tiga kali dalam satu minggu. 
(5) Lomba pidato dan drama berbahasa Arab.

Progam kebahasaan di asrama juga dilakukan guna untuk melatih kesiapan mental dalam kemampuan berbicara didepan banyak orang. Memberikan kebiasaan semacam reward bagi siswa yang beprestasi. Kegiatan ini adalah kegiatan yang biasanya dilaksanakan dalam peringatan hari-hari besar setiap tahunya, seperti peringatan hari santri nasional, hari ulang tahun asrama dan hari besar lainya. Kegiatan wajib diikuti oleh seluruh santri Asrama. Adapun kegiatan ini bertujuan untuk menjadikan para santri dalam praktek kemampuannya berbahasa Arab dan untuk mencentak santri-santri yang berprestasi dalam berbahasa Arab (Madkur, 1991).

Dalam upaya menciptakan lingkungan bahasa, pengasuh perlu melibatkan organisasi-organisasi yang melibatkan para siswa seperti para pengurus Organisasi Siswa Intra Sekolah/Intra Asrama (OSIS/OSIA). Beberapa program yang bisa dilakukan OSIS/OSIA untuk mendukukung terciptanya lingkungan bahasa, antara lain: (1) mengawasi jalannya penggunaan bahasa Arab, (2) mengontrol pelanggar bahasa, (3) mengecek buku mufradât, (4) mengagendakan kegiatan penting yang berhubungan dengan kebahasaan, (5) berkonsultasi dengan pembimbing dalam hal kebahasaan, (6) mendokumentasikan mufradât dan istilah bahasa asing yang diajarkan kepada santri asrama, (7) bekerjasama dengan asatidz/asatidzah dalam menangani para pelanggar bahasa, (8) berperan serta dalam PHBI-PHBN jika ada kegiatan yang berhubungan dengan kebahasaan, (9) membuat grafik yang memuat pelanggaran bahasa yang dilakukan penghuni asrama, (10) mengumumkan siswa yang melanggar bahasa terbanyak, (11) menentukan bahasa mingguan, (12) menentukan zona berbahasa Arab,.

Selain program kerja OSIS/OSIA, pembentukan lingkungan bahasa perlu didukung dengan adanya kegiatan ekstra-kurikuler yang intensif dan ditradisikan pada semua warga asrama. Misalnya: muhad'arah, kosa kata harian, kajian kitab klasik, pengadaan majalah dinding, lomba-lomba kebahasaan seperti:cerdascermat, cerita, pidato, dan sebagainya.

Dalam penelitian ini fokus pada analisis secara deskriptif tentang strategi pembentukan lingkungan berbahasa Arab dalam meningkatkan kemapuan berbicara bahasa Arab di asrama MAN 1 Metro.

\section{PEMBAHASAN}

Bahasa Arab yang merupakan bahasa Asing bagi siswa-siswi di Indonesia, merupakan suatu bidang studi yang tidak mudah dipelajari. Ada dua hambatan dalam mempelajarinya, yakni linguistik dan non-linguistik. Azyumardi Azra mengungkapkan, adanya ketidaksuksesan pembelajarn bahasa Arab adalah disebabkan oleh jarang adanya cendekiawan islam yang mahir menguasainya dan menurunnya tingkat minat para siswa terhadap bahasa Arab.

Untuk melakukan peningkatan dalam pembelajaran berbahasa Arab, terdapat 4 unsur yang harus terpenuhi agar efektif, yakni:

1. Memiliki positive thinking dan positive action yang tinggi dari pihak penyelenggara.

2. Menjunjung tinggi pedoman yang telah dibuat disepakati bersama, baik itu visi misi, peraturan, prosedur, struktur dan pelaksanaan.

3. Adanya tenaga pendidik yang ahli dibidangnya. Aktif, inovatif dan terintegritas.

4. Mengatur dan menyediakan dengan baik pendanaan lembaga, melengkapi sarana prasarana, memperbaiki struktur dan infrastruktur pendukung dan 
untuk mendorong penggerak dan tim kreatif untuk menciptakan lingkungan berbahasa Arab (Rizqi, 2017).

Lingkungan merupakan bagian dari elemen penting dalam pengembangan keterampilan kebahasaan seseorang. Seorang siswa dapat menguasai bahasa Arab disebabkan oleh dua faktor.

Faktor pertama menjadi faktor dalam perolehan bahasa (Iktisab al-Lughah). Akuisisi (perolehan) bahasa merupakan suatu tahapan alamiyah linguistic secara tak sadar. Oleh karena itu perolehan bahasa merupakan hasil dari hubungan komunikasi yang nyata antara siswa dan orang lain di lingkungan bahasa yang akan menjadikannya terampil secara fungsional verbal. Artiinya, mereka tidak memerlukan penguasaan teori, akan tetapi praktek akan lebih cukup diterapkan untuk mendapatkan ketrampilan tersebut. Ini juga berlaku untuk perolehan bahasa Arab, umumnya diperoleh oleh siswa karena lingkungan siswa menggunakan bahasa Arab sebagai bahasa komunikasi, atau bisa juga disebut bahasa Arab sebagai penutur asli (bahasa pertama/ibu) (Nufus, 2019).

Faktor kedua adalah pembelajaran bahasa (Ta'lim al-Lughah). Menurut Rod Ellis, pembelajaran bahasa dibagi menjadi dua jenis,yaitu natural dan formal. Jenis natural yaitu proses alamiyah yang terjadi begitu saja tanpa memerlukan seorang guru sebagai tenaga pengajarnya. Pada umumnya tipe ini terjadi pada kelompok multi bahasa (Ellis, 1989). Sedangkan, jenis formal yaitu proses pembelajaran yang melibatkanmuriddan guru danterjadi di dalam kelas secara berkali dan terjadwal serta memiliki tujuan yang sepesifik (Habibah, 2016).

Wahab menyatakan bahwa adanya penerapan lingkungan kebahasaan yang kondusif, terpandu dan terarah adalah merupakan unsur penting karena dalam lingkungan tersebut akan terjadi proses komunikasi yang akan menunjang ketrampilan bahasa anak. Disebutkan bahwa sebanyak 75\%, anak dapat mencapai pengetahuannya lewat indera penglihat, sebanyak $13 \%$ melalui indera pendengaran, dan sebanyak 12\% adalah dengan indera lain selain pendengar dan penglihatan, yakni perasa dan penciuman. Kawasan belajar dinilai lebih efektif apabila dalam kawasan tersebut diaplikasikan media-media dokumentasi seperti foto-foto dengan keterangan akan lebih memberikan hasil positif tiga kali lipat daripada Lingkungan belajar konvensional, yaitu proses pembelajaran seperti biasa dnegan disampaikan oleh guru. Namun, apabila foto-foto atau gambar dihubungkan dengan kosa kata maka akan lebih memberi keefektifan belajar enam kali lipat (Wahab, 2008).

Berdasarkan hal ini, lingkungan belajar bahasa Arab di asrama MAN 1 Metro diyakini mendukung efektivitas pembelajaran bahasa Arab di madrasah. Ini tentu menjadi sumber dan motivasi untuk belajar bahwa siswa, selain itu juga akan membanggakan institusi pendidikan yang menandakan kualitas baik dan memiliki nilai positif.

Berikut adalah fungsi diterapkannya lingkungan bahasa Arab bagi para murid:

1. Menjadikan kebiasaan diri dan keterampilan akademis dalam proses berbahasa arab dengan cara praktek percakapan (Muhadatsah), diskusi (Munaqasah), seminar (Nadwah), pelajaran (Muhadharah) dan ekspresi tertulis (Ta'birTahriri).

2. Memberi kekuatan dalam penguasaan bahasa Arab yang telah mereka dapatkan pembelajarannya di kelas 
3. Memberi peningkatan terpadu antara keefektifan antar teoritis dan praktikum yang diterapkan di lingkungan bahasa yang pada dasarnya merupakan lingkungan informal namun menarik dan disukai siswa. (Wahab, 2008: 294).

Dapat disimpulkan secara umum, bahwa tujuan terciptanya lingkungan bahasa Arab yaitu untuk upaya peningkatan kemahiran dan ketrampilan bahasa Arab untuk siswa sehingga mereka dapat menguasainya secara verbal dan nonverbal dengan baik dan benar (Nufus, 2019).

Dikatakan oleh Pavlov, yang merupakan pelopor teori behaviorisme mempercayai bahwa lingkungan belajar adalah satu satu upaya untuk meningkatkan kesuksekan para siswa dalam memperoleh kualitas dan kemahiran berbahasanya. Dalam lingkungan bahasa, terjadi stimulus alamiyah adiktif, artinya adalah siswa distimulus secara alami dan direspon dengan tanggapannya.Hal ini juga harus diterapkan pembiasaan, karena dalam kegiatan yang dilakukan secara terbiasa akan memberikan keefektifan yang lebih unggul sehingga akuisisi yang mereka dapatkan lebih besar.

Sedangkan, pendapat Chaer dan Agustina, mendukung adanya proses pembejaran yang menerapkan nuansa alami seperti adanya lingkungan kebahasaan. Karena baginya, itu dinilai lebih memberi sisi efektif daripada belajar yang dilakukan dalam kelas (Rizqi, 2017).

\section{SIMPULAN}

Pembentukan lingkungan berbahasa merupakan suatu upaya dalam meningkatkan penguasaan bahasa Arab. Salah satu sarana yang perlukan dalam pengembangan keterampilan berbicara bahasa Arab adalah ligkungan bahasa Arab. Bahasa dan lingkungan adalah dua hal yang tidak dapat dipisahkan. Bahasa adalah media yang digunakan dalam interaksi antara satu dan yang lain. Sedangkan lingkungan adalah tempat tumbuh dan berkembangnya bahasa. Lingkungan bahasa adalah sarana yang nyata dalam akuisisi bahasa untuk siswa berbahasa.

Lingkungan bahasa Arab dibedakan menjadi dua jenis, yaitu lingkungan formal (kelas) dan lingkungan informal (di luar kelas). Lingkungan formal membantu seseorang untuk belajar teori kebahasaan yang focus terhadap penguasaan aturan-aturan bahasa yang secara sadar dipelajari melalui guru dan buku. Lingkungan formal dapat memberikan hasil pengalaman yang berbeda-beda disetiap individu karena terjadinya perbedaan metode dan model pembelajaran. Sementara lingkungan informal memberikan input untuk akusisi kosa kata linguistik secara independen dalam kondisi lingkungan yang sama di setiap individu.Ini menunjukkan betapa pentingnya faktor lingkungan dalam mengembangkan bahasa kedua seseorang, terutama dalam bahasa Arab.

Adapun strategi yang bisa diterapkan dalam membentuk lingkungan bahasa di asrama MAN 1 Metro untuk mengembangkan keterampilan berbicara bahasa Arab antara lain: Pengembangan kosa kata bahasa Arab,Pemajangan kosa kata berbahasa Arab di fasilitas umum, mempratekan bahasa Arab dalam komunikasi sehari hari, praktek pidato dan drama berbahasa Arab.

\section{DAFTAR PUSTAKA}

Aflisia, N., \& Harahap, P. (2019). Eksisten Bi'ah Lughawiyah sebagai Media Berbahasa Arab dalam Meningkatkan Kemampuan Muhadatsah Mahasiswa Prodi Pendidikan Bahasa Arab IAIN Curup. Lisanul'Arab: Journal of Arabic Learning and Teaching, 8(1). 
Al-'Arabi, S. 'Abdul M. (t.t.). Ta'allum Al-lugat al-Hayyah wa Ta'lîmuha.

Amrullah, Nawawi, Sahuddin, S., \& Djuhaeni, E. (2018). Sosialisasi Pentingnya Diskusi Kelompok dalam Meningkatkan Kemampuan Berbicara Siswa untuk Guru-Guru di Pondok Pesantren Tgkh Syeikh Zainuddin Abdul Madjid Nw Anjani Kabupaten Lombok Timur. Jurnal Pendidikan dan Pengabdian Masyarakat, 1(2).

Chaer, A. (1995). Sosiologistik Perkenalan Awal. Rineka Cipta.

Dahlan, J. (1992). Metode Belajar Mengajar Bahasa Arab. Al-Ikhlas.

Dluhriah, N. A. (2017). Penerapan Al-Ibaarat Al-Yaumiyyah untuk Meningkatkan Kemampuan Berbicara Bahasa Arab Siswa SMP Islam Sabilillah Malang. Prosiding Konfererensi Nasional Bahasa Arab, 3(3).

Ellis, R. (1989). Understanding Second Language Acquisition (Vol. 31). Oxford University Press Oxford.

Habibah, N. (2016). Lingkungan Artifisial dalam Pembelajaran Bahasa Arab. Arabiyat: Jurnal Pendidikan Bahasa Arab dan Kebahasaaraban, 3(2).

Hermawan, A. (t.t.). Metodologi Pembelajaran Bahasa Arab.

Madkur, A. A. (1991). Tadris Funun Al-Lughah Al-'Arabiyyah. Daar Al-Syawwaf.

Maimunah. (2016). Pembelajaran Bahasa Arab Berbasis Humanistik. Medina-Te: Jurnal Studi Islam, 12(1).

Muayyanah, \& Anwar, K. (2019). Interferensi Fonetik dalam Keterampilan Berbicara; Studi Analisis Deskriptif di Lingkungan Mahasiswa STAI Syaichona Moh. Cholil Bangkalan. Seminar Nasional Bahasa Arab Mahasiswa III.

Nufus, H. (2019). Peranan Bi'ah Lughawaiyyah dalam Meningkatkan Kemahiran Berbahasa Arab Santri Ma'had Dar Al-Quran Tulehu Maluku Tengah. Lingue: Bahasa, Budaya, dan Sastra, 1(1).

Nurhidayati. (2003). Model Pengembangan Lingkungan di Pondok Modern Gontor Putri Mantingan Ngawi, Makalah Lokakarya Pemanfaatan Multi Media. UM Malang.

Putri, N. (2013). Bi'ah 'Arabiyah. Al-Ta lim Journal, 20(2).

Rizqi, M. R. (2017). Resonansi Bi'ah Lughowiyyah dalam Meningkatkan Akuisisi Bahasa Arab. Dar el-Ilmi: Jurnal Studi Keagamaan, Pendidikan, dan Humaniora, 4(2).

Rokiban. (2020, Juni 10). Berdasarkan Wawancara Peneliti Kepada Pimpinan Asrama MAN 1 Metro dan Merupakan Lulusan Pondok Modern Darussalam Gontor [Komunikasi pribadi].

Setyonegoro, A. (2013). Hakikat, Alasan, dan Tujuan Berbicara (Dasar Pembangun Kemampuan Berbicara Mahasiswa). Pena: Jurnal Pendidikan Bahasa dan Sastra, 2(2).

Sholeh, A. (2017). Lingkungan Behavioristik dalam Berkomunakasi Bahasa Arab di STAI Syaichona Moh. Cholil Bangkalan. Seminar Nasional Bahasa Arab Mahasiswa I. 
Susanto, Y. D. T. (2017). Hubungan Penguasaan Kosakata dengan Keterampilan Berbicara dan Menulis Siswa Kelas IV SDN Gugus Pangeran Diponegoro Kecamatan Ngaliyan [Skripsi]. Universitas Negeri Semarang.

Tarigan, G. (2013). Berbicara Sebagai Suatu Keterampilan Berbahasa. Angkasa.

Taubah, M. (2017). Menciptakan Bi'ah 'Arabiyah di Lingkungan Universitas yang Multikultural. Studi Arab, 8(2).

Unsi, B. T. (2015). Kemahiran Berbicara Bahasa Arab melalui Penciptaan Lingkungan Bahasa. Tafáqquh: Jurnal Penelitian Dan Kajian Keislaman, 3(1).

Wahab, M. A. (2008). Epistemologi dan Metodologi Pembelajaran Bahasa Arab. Lembaga Penelitian UIN Jakarta Press.

Wassid, I., \& Sunendar, D. (2008). Strategi Pembelajaran Bahasa. Remaja Rosdakarya.

Yunus, M. (1990). Kamus Arab-Indonesia. Diponegoro. 